\title{
Whether Beet Juice and Red Dragon Fruit Juice Increase the Haemoglobin Level in Young People?
}

\author{
Endang Wahyuningsih ${ }^{1 *}$, Endang Sawitri ${ }^{1}$, Choiril Hana ${ }^{1}$
}

\author{
${ }^{1}$ Sekolah Tinggi Ilmu Kesehatan Muhammadiyah Klaten, Klaten 57419, Indonesia \\ *Corresponding author. Email: endangwahyuningsih@stikesmukla.ac.id
}

\begin{abstract}
Anaemia has been one of the social health problems which arises and is spread around the world especially in developing countries and poor countries. Anaemia affects a large number of people mainly young males and females. Women and young females need twice as much iron as men and young males do. WHO states that $25-40 \%$ of young people suffer from anaemia and it strikes more than $57 \%$ of young females in Indonesia. The red beet is rich in various vitamin B content: vitamin B1, B2, B3 and B6. The dragon fruit also contains iron, vitamin B1, vitamin B2, vitamin B and vitamin C. Our research purpose is to find out the comparison of beet juice and dragon fruit juice consumption to increasing haemoglobin level in 11-15-year-old young people. The research design is Quasi-Experiment using pre-test-post-test with control group design. The technique sampling, we use is purposive sampling. We use a juice extractor and haem meter to study the samples for seven days. There were 32 samples in our research. Our research used paired t-test and independent $t$-test. The result showed that beet $p$ value was $0.515>0.05$ and dragon fruit was $0.516>0.05$ and that the consumption of beet juice and dragon fruit juice did not affect the haemoglobin level in 11-15year-old young females. Average haemoglobin level given beet $p$ value was $0.026<0.05$ and average haemoglobin level given dragon fruit $\mathrm{p}$ value was $0.033<0.05$.

Keywords: beet juice, red dragon fruit juice, haemoglobin
\end{abstract}

\section{INTRODUCTION}

Young people still show growth especially their reproductive system. During menstrual period, females need enough iron. Protein, iron and vitamin $\mathrm{C}$ intakes are related to menstrual cycle [1]. Dysmenorrhoea is an annoying problem for some women, especially for those who do intense activities like young people. One of the factors which affect dysmenorrhoea is the Hb level is less than $12 \mathrm{gr} / \%$ (anaemia) which often strikes young people. The main factor which contributes to less haemoglobin level is bleeding during menstrual period and insufficient nutrients intake. Iron and proteins young people take will reduce dysmenorrhoea and anaemia [2]. Young females face a high risk of suffering from anaemia because they have a menstrual period every month. They can increase their haemoglobin level by take vitamin $\mathrm{C}$ and tablet $\mathrm{Fe}$ [3]. Those who suffer from anaemia lack $\mathrm{Fe}, \mathrm{Zn}, \mathrm{Cu}$, folic acid and B6 intake [4]. Lack vitamin A and $\mathrm{C}$ will also affect their haemoglobin level [5]. Vegetable protein also plays an important role in anaemia development in WUS [6].

The young females' haemoglobin level who live in mountainous regions is different from that of who live in coastal regions [7]. Children who suffer from GAKI (a condition in which there is a deficiency of iodine) in Indonesia are related to anaemia. Eating habit will affect the size of anthropometry including weight, height and abdominal circumference of young people's [8]. Eating habit in which there is a deficiency of nutrient will affect the abnormality of anthropometry size which results in anaemia [9]. Young people's unhealthy life style such as consuming fast food, drinking soda, drinking unhealthy energy drinks will result in health problems and chronic diseases which are not contagious so that it increases mortality and morbidity [10]. In assosa zone, anaemia occurs in socio-demographic conditions and food intake [11]. According to the data from Muhammad Al Kaustar Junior High School, there are 235 teenagers aged 13-16. Based on the information from student department, a clinic in Kartosuro has a counselling program to measure the students' weight and height every three month. Apart from that, there has never been anaemia skimming as an early detection of anaemia in young people conducted by the school and clinic in Kartosuro. This will affect their concentration and achievements.

\section{METHOD}

Our research design used quasi experimental with research design being used was non-equivalent pre and post-test control group design. We separated the group into two groups. The first group was given beet juice and the second was given red dragon fruit juice. We checked the young females' haemoglobin level. After we collected the data, we took the respondents based on their criteria. The result from the skimming of their haemoglobin level showed that there were 32 people with abnormal haemoglobin level. After we collected the data, the respondents' data was grouped into 2 groups. In the first group, 16 respondents were given beet juice, and in the second group 16 respondents were given red dragon fruit juice. They were beet juice without water 
as much as 100 grams for 7 days by using a juice extractor. The second group were given red dragon fruit juice without water as much as 100 grams for 7 days by using a juice extractor. Then we conducted the post-test to measure the first and second's group haemoglobin level using paired t- test and independent t-test. The paired t-test was conducted to test the different mean of the two results of measurement in the same group. While the independent t-test was conducted to test the different mean of both groups of interventions/cases and the control groups.

Table 1 Measurement test

\begin{tabular}{|cccc|}
\hline Pre-measurement & Treatment group & Giving treatment & Post measurement \\
\hline $\begin{array}{c}\text { Young people haemoglobin } \\
\text { levels }\end{array}$ & group 1 & Beet juice & Haemoglobin post \\
\hline
\end{tabular}

\section{RESULTS AND DISCUSSION}

Based on the research results, it was known that the average haemoglobin level before the pre-test (before they were given beet juice) was lower which was $10.94 \mathrm{gr} / \mathrm{dl}$ compared to the average haemoglobin level after the posttest (after they were given beet juice) which was $11.58 \mathrm{gr} / \mathrm{dl}$. With the highest score of pre-test haemoglobin level (11.3 $\mathrm{gr} / \mathrm{dl})$, it was lower compared to the post test (13.6 gr/dl), and the lowest score of pre-tests was $6.7 \mathrm{gr} / \mathrm{dl}$ was lower compared to the haemoglobin level after they were given beet juice which was $9.9 \mathrm{gr} / \mathrm{dl}$. This proved that the average haemoglobin level of pre-test after beet juice was given was lower than that of post-test $(10.49 \mathrm{gr} / \mathrm{dl}<11.58 \mathrm{gr} / \mathrm{dl})$.

Based on the research results, the average haemoglobin level of pre-test (before they were given red dragon fruit juice) showed lower number which was $11.63 \mathrm{gr} / \mathrm{dl}$ compared to the average haemoglobin level of post-test (after they were given red dragon fruit juice) which was $12.36 \mathrm{gr} / \mathrm{dl}$. The haemoglobin level of pre-test with the highest score was $11.9 \mathrm{gr} / \mathrm{dl}$ and the lowest score was 10.7 $\mathrm{gr} / \mathrm{dl}$. While the average haemoglobin level of post-test (after they were given red dragon fruit juice) was $12.36 \mathrm{gr} / \mathrm{dl}$ with the highest level $14.9 \mathrm{gr} / \mathrm{dl}$ and the lowest level 10.2 $\mathrm{gr} / \mathrm{dl}$. This proved that the average haemoglobin level before they were given red dragon fruit juice was actually lower than that of after they were given red dragon fruit juice $(11.63 \mathrm{gr} / \mathrm{dl}<12.36 \mathrm{gr} / \mathrm{dl})$.

Based on the research results, it was known that the average haemoglobin level of the pre-test and post-test was different. The first group of young females given beet juice showed the paired simple t-test result was with p-value 0.26 $>0.005$. We can draw a conclusion that there is a difference between the average haemoglobin level of pre-test and posttest in the first young females' group (after they were given beet juice). From the average haemoglobin level of pre-test and post-test in the second group (after they were given red dragon fruit juice), we could get $p$-value $0.033>0.05$. This showed that there was a difference of the average haemoglobin level of pre-test and post-test in the second group (after they were given red dragon fruit juice).

The independent analysis result was used to know whether there was a difference of the average haemoglobin level of pre-test and post-test between the first and second group (after they were given beet juice and red dragon fruit juice). We obtained p-value $0.515>0.05$ for the beet group and $0.516>0.05$ for the dragon fruit group. This means that there is no difference increase in haemoglobin level of posttest in both groups given beet juice and dragon fruit juice.
We did not observe this so that the final result of the research biases because of several factors such as having breakfast habit, social economic status, and gender.

The hypothesis test with independent sample test was intended to know whether there was a difference of the average haemoglobin level of post-test in both groups (after they were given beet juice and red dragon fruit juice). We obtained p-value $0.515>0.05$ for the beet group and 0.516 $>0.05$ for dragon fruit juice. This means that there was no increase in the level haemoglobin of post-test in both groups after they were given beet juice and red dragon fruit juice at Muhammadiyah Al Kaustar Junior High School. Young females need energy, protein, and more other nutrients to grow. They need more iron than young males because it is needed to replace iron missing during menstrual period. Anaemia is a condition which there is deficiency of the capacity of oxygen carrier in blood. Fruits and vegetables containing vitamins and minerals function as antioxidants, phytoestrogen, and inflammation agent [12]. The deficiency of a number of vitamins and minerals can cause anaemia [13]. Girls who lack nutrients suffer from anaemia. Consuming tannin in the long term can affect iron status [14]. Most of young females have normal menstrual cycle [15]. Consuming fruits containing vitamin $\mathrm{C}$ such as beet can increase the haemoglobin level and limits food intake which can be an inhibitor [16]. Fe affects the optimization of $\mathrm{Fe}$ abortion in body. Consuming iron in 7 days will increase the haemoglobin level. Haemoglobin is a protein rich in iron. Protein plays an important part in transporting iron in body which leads to a problem if there is a deficiency of iron. The lower protein and iron intakes are, the lower the level of haemoglobin is [17]. The dragon fruit is a cactus of Hylorecceus and selenicereus. Although it is a new kind of fruit in Indonesia, many people consume this fruit as a medicine for increasing stamina and blood cells.

\section{CONCLUSION}

The consumption of beet juice and dragon fruit juice did not affect the haemoglobin level in young females because of several factors such as having breakfast habit good, social economic status, and gender. Research juice is an effective method to promote the consumption of fruits and vegetables as well as a balanced diet which offer to reduce high risks of various diseases. 
[8] H. Ashar, D. K. Mulyantoro, Y. D. Nurcahyani, and M. Khaerunnisa, “Anemia Pada Anak Sekolah Dasar Di Daerah Endemik Gaki," MGMI, vol. 7, no. 2, pp. 9198, 2016.

[9] D. Handayani, E. P. Pamungkasari, and E. S. Sulaeman, "Application of Path Analysis on Incidence of Anemia in Female Adolescents," J. Gizi Pangan, vol. 14, no. 1, pp. 37-44, 2019.

[10] O. Article, B. H. Rashidi, H. M. Afzali, F. Haghollahi, G. Ardalan, and H. K. Jaliseh, "Evaluation of some diet habit and physical activity in adolescents in Tehran (2011)," JQUMS, vol. 22, no. 1, pp. 13-23, 2018 .

[11] A. Abay, H. W. Yalew, and A. Tariku, "Determinants of prenatal anemia in Ethiopia," pp. 1$10,2017$.

[12] J. L. Slavin and B. Lloyd, "Health Bene fi ts of Fruits and Vegetables 1,” pp. 506-516, 2012.

[13] P. K. Goswami, S. Ghodgaonkar, and G. V. anagha raut Vishwakarma, "Contribution of medicinal plants in treatment of anaemia and as a haematinic," J. Pharm. Pharm. Sci., vol. 4, no. 11, pp. 687-702, 2015.

[4] E. A. M. Citta Cendani, “Asupan Mikronutrien, Kadar Hemoglobin dan Kesegaran Jasmani Remaja Putri," Med. Med. Indones., vol. 45, no. 1, pp. 26-33, 2011.

[5] D. Siallagan, P. D. Swamilaksita, and D. Angkasa, "Pengaruh asupan Fe, vitamin A, vitamin B12, dan vitamin $\mathrm{C}$ terhadap kadar hemoglobin pada remaja vegan," J. Gizi Klin. Indones., vol. 13, no. 2, pp. 67-74, 2016.

[6] F. A. Nugroho, D. Handayani, and Y. Apriani, "Asupan Protein Nabati Dan Kejadian Anemia," J. Gizi Pangan, vol. 10, no. November, pp. 165-170, 2015.

[7] M. C. Jacobus and A. umboh Umboh, "Perbedaan kadar hemoglobin pada remaja gizi baik yang tinggal di pegunungan dengan yang tinggal di tepi pantai," Jurna e-Clinic (eCI), vol. 4, no. 1, 2016.
[14] N. M. Delimont, M. D. Haub, and B. L. Lindshield, "The Impact of Tannin Consumption on Iron Bioavailability and Status : A Narrative Review 1 , 2," Curr. Dev. Nutr., pp. 1-12, 2012.

[15] Z. Y. Saira Dars, Khashia Sayed, "Relationship of menstrual irregularities to BMI and nutritional status in adolescent girls," J. Med. Sci., vol. 30, no. 1, 2014.

[16] S. A. N. Eti Rimawati, Erna Kusumawati, Elviera Gamelia, Sumarah, "Food Supplement Intervention For Increasing Hemoglobin Level On Pregnant Women," J. Ilmu Kesehat. Masy., vol. 9, no. November, pp. 161170, 2018.

[17] A. H. Al Rahmad, "Pengaruh Asupan Protein dan Zat Besi (Fe) terhadap Kadar Hemoglobin pada Wanita Bekerja," J. Kesehat., vol. VIII, no. 3, pp. 321-325, 2017. 